\title{
Control of Chagas disease vectors
}

\author{
JM Ramsey, PhD, (1) CJ Schofield, PhD. (2)
}

\section{Ramsey JM, Schofield CJ. Control of Chagas disease vectors. Salud Publica Mex 2003;45:123-128. The English version of this paper is available too at: http://www.insp.mx/salud/index.html}

\begin{abstract}
A bstract
Most Latin American countries are making dramatic progress in controlling Chagas disease, through a series of national and international initiatives focusing on elimination of domestic populations of Triatominae, improved screening of blood donors, and clinical support and treatment of persons infected with Trypanosoma cruzi. Some countries, particularly U ruguay, Chile and Brazil, are sufficiently advanced in their programmes to initiate detailed planning of the subsequent phases of Chagas disease control, while others such as Peru, Ecuador, and Mexico, are currently applying only the initial phases of the control campaigns. In this review, we seek to provide a brief history of the campaigns as a basis for discussion of future interventions. 0 ur aim is to relate operational needs to the underlying biological aspects that have made C hagas disease so serio us in Latin A merica but have also revealed the epidemiological vulnerability of this disease. The English version of this paper is available too at: http://www.insp.mx/salud/index.html
\end{abstract}

Key words: Chagas disease, Triatominae, vector control;Mexi-

Key

(1) CISEl, Instituto Nacional de Salud Publica, Cuernavaca Morelos, Mexico.

(2) ECLAT Coordinator, LSHTM, London W C1 E7HT, UK.

Received on: July 29, 2002 • Accepted on: February 11, 2002

Address reprint requests to: D r. Janine M. Ramsey W illoquet. Dirección de Enfermedades Transmitidas por Vectores. Centro de Investigación sobre Enfermedades Infecciosas. Instituto N acional de Salud Pública. Avenida U niversidad 655 colonia Santa María A huacatitlán 625098, Cuernavaca, Morelos, México.

E-mail: jramsey@ insp.mx

\author{
Ramsey JM, Schofield CJ. \\ Control de vectores de la enfermedad de Chagas. \\ Salud Publica Mex 2003;45:123-128. \\ El texto completo en inglés de este artículo también \\ está disponible en: http://www.insp.mx/salud/index.html
}

\section{Resumen}

La mayo ría de los países en América Latina está avanzando, con pasos importantes, en las tareas de control de la enfermedad de Chagas por medio de iniciativas nacionales e internacionales enfocadas en la eliminación de poblaciones domésticas de Triatominae, en el tamizaje de la sangre de transfusión, y en el apoyo terapeútico para los casos infectados con Trypanosoma cruzi.Algunos países como U ruguay, C hile y Brasil, están ya adelantados en sus programas y en la planeación de las siguientes fases de vigilancia y control. Sin embargo, otros países como Perú, Ecuador y México se encuentran apenas en las fases iniciales de planeación de las campañas de control. Este ensayo revisa brevemente la historia de las campañas, como fundamento para entender las estrategias para intervenciones futuras. $N$ uestro propósito es relacionar las necesidades operacionales con los aspectos biológicos que han provocado las dimensiones de la enfermedad de Chagas en todaA mérica Latina, y que también han manifestado su vulnerabilidad epidemiológica. El texto completo en inglés de este artículo también está disponible en: http://www.insp.mx/salud/index.html

Palabras clave: enfermedad de Chagas; Triatominae; control de vectores; México 
C hagas disease control has become a significant success story of the last decade, implemented through a series of regional and multinational initiatives focused primarily on the elimination of domestic vectors, together with improved screening of blood donors and supportive treatment for those already infected. This success is seen internationally, and forms the basis for other large-scale disease control initiatives, such as the Pan African Tsetse and Trypanosomiasis Eradication Campaign (PATTEC) recently launched by the Organisation of African Unity (now African Union) ${ }^{1}$. However, in spite of the successes, there are clear problems in maintaining continuity of action, consolidation of the advancements made, and in preparing for future scenarios when the emphasis may change away from vector control and back to clinical surveillance and treatment. $^{2}$

Vector control is not the panacea for Chagas dissease control. It is better viewed as the means to eliminate domestic populations of Triatominae and to monitor the ever-present risk posed by sylvatic bugs. We have very well-proven techniques to eliminate any and all domestic populations of Triatominae, which makes it entirely unethical to condemn rural communities to living in houses infested with these large blood-sucking insects. Irrespective of their role as vectors, domestic Triatominae can contribute to chronic blood-loss, with estimated average rates of around $2.5 \mathrm{ml}$ blood loss per person per day in houses infested with Rhodnius prolixus in Venezuela ${ }^{3}$ or Triatoma infestans in Brazil and Argentina. ${ }^{4}$ It is but an unhappy myth that rural communities do not care. This may have once been the case in some areas, but even rural communities are becoming increasingly aware that domestic Triatominae are not good for them. It is not pleasant to sleep in a house infested with Triatominae, and any who might argue against vector control should be invited to try.

But although the focus of this review is on the elimination of domestic Triatominae, we feel it is important to place this within the broader context of Chagas disease control. We want to emphasise that although domestic bug populations can be eliminated, thus reducing transmission to a mere fraction of its previous levels, sylvatic bug populations will continue to exist. This means that occasional new cases of human infection may continue to occur, and it will be incumbent on the clinical surveillance services to improve their procedures for prompt diagnosis and treatment. In essence, there are two basic transmission patterns for Chagas disease which we refer to here as sylvatic and domestic. The domestic pattern derives from the original sylvatic pattern, and is currently much more important. Available vector control methods can eliminate domestic transmission, but the risk posed by the sylvatic transmission cycle will remain.

\section{Patterns of transmission}

\section{Sylvatic transmission patterns}

As a zoonotic infection of wild mammals, the etiologic agent of Chagas disease -Trypanosoma cruzi- is widespread in the Americas, from the Great Lakes of North America to Southern Patagonia (roughly between latitudes $42^{\circ} \mathrm{N}$ and $46^{\circ} \mathrm{S}$ ). Didelphid opossums are amongst the most important wild reservoirs, as are other nest-building mammals such as caviid and murine rodents, and armadillos. There is some evidence to suggest that opossums may have been the original hosts and vectors of T. cruzi, with the parasite passed directly between these marsupials in their anal gland secretions and urine. Under this theory, the more recent advent of blood-sucking reduviids (Triatominae) would have provided the mechanism to vector T. cruzi into other mammals, contributing the current strain diversity of the parasite. ${ }^{5}$

The basic pattern of vector-borne transmission of T. cruzi thus involves sylvatic species of Triatominae vectoring the parasite from one mammal to another. We can envisage a process whereby a sylvatic vector population occupies an opossum lodge, and becomes infected by feeding on the infected opossums. Then, when the lodge is used by another mammal, such as a rodent, the parasite may be passed on and carried by the newly infected rodent to another nest -perhaps to be transmitted to other rodents by another triatomine population occupying the rodent nest. For each individual triatomine bug, the probability of becoming infected with $T$. cruzi increases in accordance with the number of bloodmeals taken, so that older bugs -especially adults- tend to have the highest infection rates. As a stable ecological system, this type of sylvatic transmission has little epidemiological importance in terms of human infection. But introduction of instability, such as drought, flood, deforestation, urbanization, or other events that lead to mortality or emigration of the mammals, can result in the triatomine population becoming hungry. Hungry adult bugs tend to fly. ${ }^{6}$

Flying adult Triatominae may be attracted to light, heat, or certain odours, or they may simply encounter a human dwelling by chance. Hungry bugs transported passively from sylvan areas due to movement of housing materials or harvest may also find themselves in a human dwelling. In such a dwelling they may encounter people and domestic animals, offering the 
possibility of a bloodmeal, and also offering the possibility of transmission of T. cruzi to people. In some cases, the adventitious bug may not even feed on a person, but simply contaminates foodstuffs or beverages that are then consumed by people living in the house - an increasing problem in the Amazon Region. ${ }^{7}$ The result may be an acute case of Chagas disease, but not necessarily involving domestic vector species. In fact, the newly-arrived triatomine bug may not succeed in colonising the house. So far in our story, there is no role for vector control. Instead, control of the disease relies primarily upon adequate case detection and treatment -oriented by good epidemiological and entomological knowledge- that can indicate where (and sometimes when) such cases might be expected to occur.

\section{Domestic transmission patterns}

Following our précis of the sylvatic story, it is evident that the derived domestic transmission pattern has become much more important in epidemiological terms. But it is over-simplistic to state that some sylvatic bugs have 'adapted' to domestic habitats where they colonise and transmit $T$. cruzi amongst the inhabitants of the house. Domestication of Triatominae is a complex process, with important genetic and phenotypic consequences -many of which favour our existing techniques for vector control.

The transition from sylvatic to domestic is mediated by major changes in habitat stability. Sylvatic habitats are less stable than domestic habitats in two key aspects. Domestic habitats offer greater protection from climatic extremes, meaning that the bugs can reproduce more continuously -less subject to the influence of seasonal climatic changes. Domestic habitats also offer greater access to blood sources, and these blood sources -people and domestic animals- are more readily available throughout the year. So domestic bugs can feed well, reproduce more quickly and more often, and so their numerical density tends to increase towards the limit of available resources. At this point however, their rate of population growth must slow -in other words, their net rate of population increase must tend to unity and the population becomes, on average, stable, neither increasing nor decreasing. So at this point, each female bug of the population is having, on average, one female offspring that reaches reproductive age (more, and the population would increase, less and it would decline). But since each female bug retains the capacity to lay 100 or more eggs, of which at least half would be female, this results in intense inter-sibling competition -the majority of her off- spring will not reach reproductive age. ${ }^{8}$ This produces an intense selection pressure for the most energeticallyefficient offspring, leading to physiological simplification that appears to be reflected even in simplification of the genome and reduction in total DNA. ${ }^{9}$

The consequences of this domestic transition, summarised in Table I, lead to a high degree of genetic homogeneity amongst each domestic triatomine population. ${ }^{10}$ There is very little variability against which to select new attributes such as insecticide resistance, which probably explains why insecticide resistance has never been an operational problem in campaigns against domestic Triatominae. But there is one consequence that is extremely unhelpful in terms of dissemination of vectors and vector control campaigns. Selection for energetic efficiency can lead to selection against flight capacity. Domestic Triatominae become less likely to disperse by active flight, and very much more dependent on their vertebrate hosts for dispersal. They are carried around by people, amongst the belongings of travellers and visitors from one house to another.

Dispersal in association with people can lead to domestic Triatominae being carried over large distances, often into areas that would not have offered suitable sylvatic habitats for that species. Examples include the finding of $T$. infestans in houses in the cooler Southern regions of Argentina (J.W. Abalos, pers. comm. 1978), or in a luxury apartment in Palermo, Buenos Aires (E.Segura, pers. comm. 1999), or of T. barberi in Mexico City (O. Velasco, pers. comm. 1996). In fact, much of the spread of $T$. infestans throughout the southern cone countries can be attributed to passive dispersal in association with human migrations, ${ }^{11}$ and the spread of $R$. prolixus from Venezuela into Colombia and parts of Central America is also believed to

\section{Table I \\ EXPeCted CONSEQUenCes OF THE DOMESTICATION OF TRIATOM M AE}

\footnotetext{
- Increased metabolic efficiency

- Reduced population variability (but drift may lead to variability in neutral genes)

- Reduced capacity for active dispersal (including some atrophy of flight muscles)

- Simplified sensorial system

- Reduced size

- Reduced fecundity (but increased egg size)

Genomic simplification
}

N ote that because of genetic simplification, most of these changes will probably be irreversible 
have been due primarily to accidental carriage by humans. ${ }^{12,13}$ Also T. dimidiata -although apparently spread as a natural sylvatic cline along most of Central America- appears to have been spread from Mexico directly to Ecuador along pre-Columbian maritime routes, ${ }^{14}$ and there is evidence that $R$. ecuadoriensis may have reached Northern Peru by being carried in lorries returning after delivering Peruvian grapes to Ecuador (F.Vargas, pers. comm. 2001). T. phyllosoma in Mexico appears periodically outside its natural range in the Sierra Zapoteca of Oaxaca due to transport of agave plants for tequila processing to the northeastern regions of Jalisco (J. Ramsey, unpublished), while T. nitida has now become established in the Sierra Zapoteca - probably due to illegal immigrant migratory routes from Central America to the Mexican-US border. ${ }^{15}$

\section{Domestic Triatominae as targets for vector control}

In essence, there are two types of domestic Triatominae. There are those such as T. brasiliensis in NE Brasil, or T. dimidiata in Central America, that have colonised local domestic habitats, and where we can expect (and in some cases has been confirmed by genetic analyses) continuous contact between the domestic populations and the conspecific sylvatic populations in the same areas. In such cases, the domestic populations can be eliminated, but continual monitoring is then required to enable selective action to eliminate any newly constituted domestic populations. The essential strategy involves insecticide spraying of all houses in localities with high rates of house infestation, until the average house infestation rate (i.e. proportion of houses infested) is brought below a predetermined level. At this point, the strategy switches to one of community-based vigilance, from which spraying is carried out only in those houses where the presence of bugs has been confirmed. This is the successful strategy now being employed against T. brasiliensis in NE Brazil ${ }^{16}$ and has been successfully evaluated as the preferred strategy against T. dimidiata in Central America. ${ }^{17,18}$

Other domestic triatomine populations appear to have been carried by people to new areas, where they have become genetically isolated from their original sylvatic conspecifics. Examples include T. infestans throughout the Southern Cone (which has sylvatic populations only in limited foci in central Bolivia), R. prolixus in Central America and Southern Mexico, T. dimidiata in Ecuador and Northern Peru, and R. ecuadoriensis in northern Peru. These latter populations are genetically highly restricted, having gone through a series of genetic bottlenecks during their dispersal, as well as the intense selection of inter-sibling competition discussed above. ${ }^{9}$ They are in regions generally unsuitable for the species, surviving only in the protected habitat offered by human dwellings. They are candidates for complete eradication. The control strategy is similar, but involves spraying all houses in infested localities, irrespective of the house infestation rate, followed by vigilance and selective intervention until no bugs have been encountered for a period of at least 3 years. Moreover, the entire geographic range of the target populations must be dealt with, in order to ensure that bugs are not accidentally carried in from untreated localities.

For both operational strategies, the control techniques are similar. The entire internal surface of the infested premises is sprayed, together with furniture and any peridomestic dependencies such as chicken coops, goat corrals, latrines and so on. Spraying is carried out by professional teams using professional equipment, applying recommended dose rates of approved products (see Table II). Guides to the equipment, products, and procedures have been published

Table II

Products recommended for the control of domestic Triato minae

\begin{tabular}{lllll} 
Product & $\begin{array}{c}\text { Formulation SC-suspension concentrate; } \\
\text { W P-wettable powder }\end{array}$ & Application rate (mg a.i./m_) & Main manufacturer & Trade names \\
Deltamethrin & SC & 25 & Aventis & K-othrine-Biothrine \\
\hline Lambda-cyhalothrin & W P & 30 & Zeneca -Syngenta & Icon-Commodore \\
\hline Cyfluthrin & W P & 50 & Bayer & Solfac \\
\hline Betacyfluthrin & SC & 25 & Bayer & Responsar \\
\hline Cypermethrin & W P & 125 & Various & Various
\end{tabular}

N ote: D eltamethrin, lambda-cyhalothrin and cyfluthrin have been evaluated and passed by the W HO pesticide evaluation scheme (W HO PES); betacyfluthrin is in the final evaluation stages; cypermethrin has not been evaluated by W HO PES for Chagas disease vectors 
by the World Health Organization (www.who.int/ctd/ $\mathrm{html} /$ whopes.html) or are available on request ( $\mathrm{Dr}$ Morteza Zaim, WHOPES, WHO, 1211 Geneva 27, Switzerland).

\section{Present and future of Chagas disease control}

Since the launch of the Southern Cone initiative in 1991, Latin America has made tremendous advances in the control of Chagas disease. Already Uruguay, Chile, most of Southern and Central Brazil, and four previously endemic provinces of Argentina have been formally certified by PAHO as free of Chagas disease transmission. Large areas of Paraguay and Southern Bolivia are also free of vector-borne transmission, with some progress also in Southern Peru (Tacna). In Central America, R. prolixus now seems to have been eliminated from El Salvador and from large parts of the previously endemic regions of Guatemala, Honduras and Nicaragua. Mexico also, although only just beginning to plan large-scale campaigns against Chagas disease ${ }^{19}$ appears already to have almost eliminated $R$. prolixus from the Southern states. ${ }^{15,20}$ The medical and social benefits have been dramatic. Even the poorest families in controlled areas can now construct even the humblest of dwellings, and sleep without the risk of nuisance, blood-loss, and T. cruzi transmission due to domestic bugs. Even for people already infected with T. cruzi, the likelihood of developing chronic lesions seems to have declined ${ }^{2}$-possibly due to absence of reinfection. ${ }^{21}$

The consolidation and surveillance phases are also well underway in many countries. Even areas with virtually no previous history of Chagas disease transmission, such as Belize and Suriname, now have organised entomological, serological and clinical surveillance procedures, designed to inhibit future transmission. But it is a mistake to believe that Chagas disease is conquered. Regions such as Northern Peru, Ecuador, much of Venezuela and Colombia, Guyana, French Guiana, Costa Rica and Panama, have yet to implement fully prioritised surveillance and control campaigns against Chagas disease and its vectors. Mexico is only just beginning. And even countries such as Uruguay and Argentina, with a long and successful tradition of successful Chagas disease control, now suffer the paradoxical "castigo del éxito" (burden of success). Success tends to bring the "punishment" of reduced resources and declining interest on the part of government services -risking recrudescence of transmission in previously controlled areas. This is a serious mistake, as even the simplest of economic models will show. For the Southern Cone programme for example, economic analyses show benefits accruing at the rate of over US\$53 million per year (dollars valued at 1990 levels) provided vigilance is maintained and there is no recrudescence of vector-borne transmission in treated areas. By contrast, abandoning epidemiological surveillance would save only around $5 \%$ of total intervention costs, but would reduce overall benefits by over $33 \% .^{22}$

In regions where the primary domestic vectors have been targeted for eradication -the Southern Cone (T. infestans), Central America (R. prolixus), Ecuador and Northern Peru (T. dimidiata), it is vital to complete the task. This seems technically feasible, as shown by the rapidity of success in so many areas, and will greatly contribute to the well-being of rural communities. ${ }^{23}$ But in these areas and elsewhere, the need is to adopt a sustainable system of reporting the presence of any domestic triatomine recurrence, backed by a well-trained professional service able to intervene with selective actions to prevent the establishment of spread of domestic bug populations. The strategies have been trialled, and seem to be highly cost-effective. ${ }^{17}$ And if widely adopted, we believe it will be possible to maintain Latin American communities free of domestic Chagas disease vectors. At this point-if achieved-vector control will no longer be the primary arm of Chagas disease control. We would have reverted to the original pattern of $T$. cruzi transmission, involving adventitious sylvatic vectors and occasional cases of acute infection (see above). There would be a need in some areas to monitor the entomological scenario, with selective action against any vector population that might reinitiate domestic colonisation, although this may become progressively less likely with improving standards of rural accommodation. But ecological change -accelerating in many regions of Latin America- would forever presage the possibility of sylvatic bugs leaving their sylvatic homes and potentially entering ours.

We can target such regions of risk, using, for example, predictive geographic models of vector and host distribution, overlaid with patterns of human land use. $^{24}$ We can relate such models to real-time changes in land use using remotely-sensed satellite data, ${ }^{25}$ and from this guide the surveillance services in terms of where and when to expect possible transmission due to sylvatic vectors. But such ideas are entirely contingent on the idea that clinical medical services would be developed sufficiently to offer prompt diagnosis of new acute cases, and able to initiate prompt remedial therapy. Such services have yet to be developed in most parts of Latin America. Clinical training in Chagas disease diagnosis is not a major feature in the curriculum of many Latin American Schools of Medicine -in 
some countries, it has been estimated that some clinical courses now devote no more than 30 minutes to Chagas disease within a 6-year course of medical training.

Historical appraisals show that it is primarily the scientific community of Latin America -and particularly the clinical medical community- that has provided the knowledge, rationale and political influence that has promoted and shaped the successful campaigns against Chagas disease. ${ }^{26}$ They must continue to do so, but we believe they must also prepare for the future -when domestic populations of Triatominae become rare, while occasional new acute cases may continue to occur.

\section{Acknowledgements}

We express particular thanks to the many colleagues who have shaped our views on Chagas disease control, and place on record our admiration for those who have led and implemented the Chagas disease control initiatives throughout Latin America. We also congratulate Dr Edgardo Schapachnik for his moderation of the Chagas forum, and the many contributors who have enriched it.

\section{References}

1. Kabayo J. Aiming to eliminate tsetse from Africa. Trends Parasitol 2002;18:534-536

2. Dias JCP, SilveiraAC, Schofield CJ.The impact of $C$ hagas disease control in Latin America. Mem Inst 0 swaldo Cruz 2000;97:603-612.

3. Rabinovich JE, Leal JA, Pinero D F.D omiciliary biting frequency and blood ingestion of the $C$ hagas disease vector Rhodnius prolixus Stahl (Hemiptera: Reduviidae) in Venezuela. Trans Roy Soc Trop Med Hyg 1979;73:272-283.

4. Schofield CJ. Chagas disease, triatomine bugs, and blood-loss. Lancet 1981:1316.

5. Schofield CJ. Trypanosoma cruzi - The vector-parasite paradox. Mem Inst 0 swaldo Cruz 2000;95:535-544.

6. Lehane MJ, McEwan PK,W hitaker CJ, Schofield CJ.The role of temperature and nutritional dependence in flight initiation by Triatoma infestans. ActaTropica 1992;52:27-38.

7. Coura JR, Junqueira ACV, Fernandes 0 ,Valente SAS, Miles MA. Emerging Chagas disease in Amazonian Brasil.Trends in Parasitol 2002;18:171-176. 8. Schofield CJ, Diotaiuti L, Dujardin JP.The process of domestication in Triatominae. Mem Inst O swaldo Cruz 1999;94:375-378.
9. D ujardin JP, Schofield CJ, Panzera F. Les Vecteurs de la maladie de Chagas. Recherches taxonomiques, biologiques et génétiques. Brussels: A cademie Royale des Sciences d'O utre Mer, 2000.

10. D ujardin JP, Schofield CJ,Tibayrenc M. Population structure of Andean Triatoma infestans: Allozyme frequencies and their epidemiological relevance. Med Vet Entomol 1998;12:20-29.

11. Schofield CJ. Biosystematics of the Triatominae. En: Service MW, comp. Biosystematics of haemato phagous insects. 0 xford: Clarendon Press, 1988:284-312.

12. Dujardin JP, Muñoz M, Chávez T, Ponce C, Moreno J, Schofield CJ.The origin of Rhodnius prolixus in Central America. Med Vet Entomol 1998:12:113-115.

13. Schofield CJ, D ujardin JP.Theories on the evolution of Rhodnius. Actual Biol 1999;70:183-197.

14. A bad-Franch F, Paucar CA, Carpio CC, C uba-Cuba CA,A guilar VH M, Miles MA. Biogeography of Triatominae in Ecuador: Implications for the design of control strategies. Mem Inst 0 swaldo Cruz 2001;96:611-620.

15. Ramsey JM, 0 rdóñez $R$, C ruz-C elis A, Alvear AL, Chávez V, López $R$ et al. D istribution of domestic Triatominae and stratification of $C$ hagas disease transmission in 0 axaca, Mexico. Med Vet Entomol 2000;14:1-12. 16. Dias JCP, D iotaiuti L.Triatomineos e seu controle no Brasil: Perspectivas e desafios. Cadernos de Saude Publica 2000; 6 suppl 2:1-126.

17. A cevedo F, Godoy E, Schofield CJ. Comparison of inter vention strategies for control of Triatoma dimidiata in N icaragua. Mem Inst 0 swaldo Cruz 2000;95:867-871.

18. Pan American Health 0 rganization. Taller para el establecimiento de pautas técnicas en el control de Triatoma dimidiata. El Salvador: Pan A merican Health 0 rganization, 2002 (in press).

19. Ramsey JM, Pohls JL, Tello-López A. Memorias del Taller para la vigilancia y el control de la Enfermedad de Chagas en la República Mexicana. Cuernavaca, Morelos, México:Instituto $\mathrm{N}$ acional de Salud Pública (in press). 20.Vidal-A costaV, Ibáñez-Bernal S, Martínez-C ampos C. Infección natural de chinches Triatominae con Trypanosoma cruzi asociados a la vivienda humana en México. Salud Publica Mex 2000;42:496-503.

21. Bustamente JM, Rivarola HW, Fernández AR, Enders JE, Fretes R, Palma $J A$ et al. Trypanosoma cruzi reinfections in mice determine the severity of cardiac damage. Int J Parasitol 2002;32:889-896.

22.Akhavan D.Análise de custo-efetividade do Programa de Controle da D oença de Chagas no Brasil. Brasilia: O rganização Pan-Americana da Saúde, 2000.

23. Briceño-León R. La enfermedad de Chagas: una construcción social. En: Briceño-León R, Dias JCP, comp. Las enfermedades tropicales en la so ciedad contemporánea. Acta Cient Venez 1993;44:257-282.

24. Peterson AT, Sánchez-C ordero V, Beard CB, Ramsey JM. Ecologic niche modelling and potential reservoirs for Chagas disease, Mexico. Emerg Infect $D$ is 2002; 8:662-667.

25. Gorla DE. La reconstrucción de la distribución geográfica de Triatominae en base a información de variables ambientales. Proceedings of the Fourth International Workshop on Population Genetics and Control of Triatominae; 2000 agosto 22-24; Cartagena de Indias, Colombia.

26. Dias JCP, Schofield CJ. The evolution of Chagas disease (American Trypanosomiasis) control after 90 years since $\mathrm{C}$ arlos $\mathrm{C}$ hagas discovery. Mem Inst O swaldo Cruz 1999:94:103-121. 